\title{
Diving Deep into Digital Literacy: Emerging Methods for Research
}

Author accepted manuscript (April 2015)

Journal: Language and Education

To be cited as:

Bhatt, I, de Roock, R \& Adams, J. (2015). Diving deep into digital literacy: emerging methods for research, Language and Education, 29(6), pp. 477-492

doi: http://dx.doi.org/10.1080/09500782.2015.1041972

Ibrar Bhatt ${ }^{1}$

Department of Educational Research, Lancaster University, Lancaster, UK

Roberto de Roock

Center for Games \& Impact, Arizona State University, Tempe AZ, USA

Jonathon Adams

English Language Institute of Singapore, Singapore 109433

${ }^{1}$ Corresponding author. Email: i.bhatt@lancaster.ac.uk 


\section{Diving Deep into Digital Literacy: Emerging Methods for Research}

Literacy Studies approaches have tended to adopt a position which enables ethnographic explorations of a wide range of 'literacies'. An important issue arising is the new challenge required for researchers to capture, manage, and analyse data that highlight the unique character of practices around texts in digital environments. Such inquiries, we argue, require multiple elements of data to be captured and analysed as part of effective literacy ethnographies. These include such things as the unfolding of digital texts, the activities around them, and features of the surrounding social and material environment.

This paper addresses these methodological issues drawing from three educationally-focused studies, and reporting their experiences and insights within uniquely different contexts. We deal with the issue of adopting new digital methods for literacy research through the notion of a 'deep dive' to explore educational tasks in classrooms. Through a discussion of how we approached the capture and analysis of our data, we present methods to better understand digital literacies in education. We then outline challenges posed by our methods, how they can be used more broadly for researching interaction in digital environments, and how they augment transdisciplinary debates and trends in research methods.

Keywords: digital literacy; CAQDAS; literacy studies, digital methods, ethnography 


\section{Introduction: a 'deep dive' excerpt}

We begin with the following vignette extract adapted from Bhatt's (2014) research study. The account is based on a few minutes of a recording of one college student, Sara, as she works on her course assignment in the classroom. The vignette is drawn mostly from a multidimensional screen-in-screen recording, which we discuss later in the paper, and Bhatt's ethnographic notes of the institutional context.

\section{Recording time: 0:00 - 6:33}

Sara is eighteen years old and a student of a Level 3 Certificate in Childcare programme at a Further Education ${ }^{2}$ college in West Yorkshire (UK). She is about to start an assignment in a writing workshop having just had a break, before which was a lecture-like session outlining the assessment criteria she is set to cover in her task.

The session begins when all the students enter the classroom, having just had their break. The teacher announces: 'ladies, bags off the tables'. They are quite chatty at this point whilst setting themselves up for the writing session.

The particular unit of the syllabus and assessment criterion ('E5: Child Protection Policies') being covered for this assignment task is up on the board as well as in front of Sara at her desk. Instead of carefully reading these texts, without a moment's hesitation she opens up an assignment from the previous unit criterion. She plugs in her USB drive, and locates and opens files and folders. These are well organised files and folders mobilised immediately into action on her screen.

She scrolls through sections of the texts of previous assignments, highlights and deletes sections, and incorporates others into a new file within the same folder of collected work, keeping elements of the previous text. What follows is a swift movement between files open in different windows on her laptop. Judiciously

\footnotetext{
${ }^{2}$ The Further Education sector in the United Kingdom consists of young people undergoing second-chance school education, degree-level programmes and a plethora of vocational courses as part of British 'post-compulsory' education.
} 
archived previous work allows her to open her files quickly, move between them, and interweave the contents of a previous assignment into the current file. She does this whilst discussing henna styles with Lauren (the student beside her). The writing of the new assignment is already well under way.

Sara then starts discussing the assignment's contents further, repeating the same questions that she asked the teacher to Lauren beside her, as she glances at the whiteboard instructions, her already notes from the previous session, and her screen. This includes guessing and working out what is required in terms of format and submission. She discusses its contents with Lauren who says that she will just copy and paste...' from a similar previous assignment, '...cos it's our own words anyway'.

She stops typing, pauses, and then refers to Google for information on 'child protection'. The algorithm 's interruptions and suggestions leave her stumbled, so she asks Lauren and the teacher again for help.

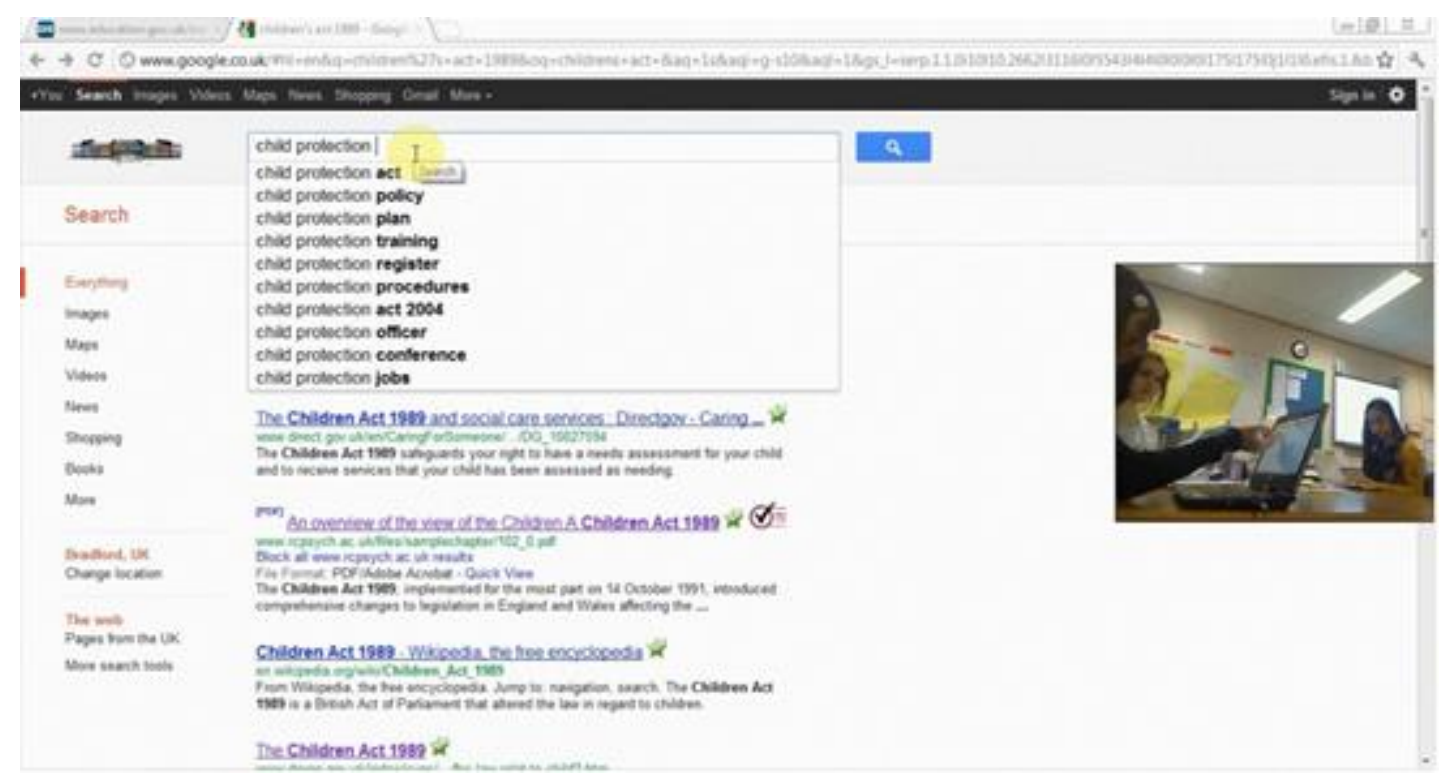

Figure 1. Sara refers to Google for help (screen-in-screen format, source: Bhatt 2014) 
What emerges in less than seven minutes into a classroom writing session is a complex interplay of digital literacy practices (a notion outlined below) in an extensive amount of intertextual work (Barthes \& Heath 1977), through a deluge of digitally mediated information. Sara has many strategies to cope with this. These include her selection and arrangement of digital content or practices some have described as 'curation' (Bhatt 2014b; Snyder 2015), evaluating the relevance of such content through practices of 'crap-detection' (Rheingold 2012), and the transposing of other writers' ideas and texts to reduce workload (dubbed 'pseudo-writing' by Skaar 2014). This assemblage of practices emerges via, and is negotiated by, an entanglement of people and things. This includes the obvious human interactants, the whiteboard display, notes on Sara's desk, her previous assignments, Web-based reports, algorithmic suggestions and directions, and a host of other stimuli being accessed and appropriated almost all at once. Practices emerging also include 'unofficial' literacy practices such as chats with Lauren and later on in the session - contacting a friend on Facebook through a personal device (see Bhatt 2012 for a discussion). But here we get to see how such practices - and others like them - are mobilised into a piece of class work.

For Sara, therefore, there emerges little that is exclusively 'vernacular' or 'academic' in the digital literacy practices drawn into her assignment. Instead, what emerges to us is an assignment that is 'assembled' by a choreography of practices. These practices hail from their own worlds (the formal and informal, curricular as well as social lives, etc.) as they, in turn, enact the precarious world of her assignment writing. The assignment's apparent end completion suggests a reality that is really the hanging together of these practices choreographed to attain a particular effect. This is the 'performativity of practice' (Law 2012: 161) as applied to literacy, and means careful attention should be paid to the ecology of practices (their contestations, 
impasses, breakthroughs, work-arounds, etc.) in a literacy event to see how sociomaterial relations - entanglements of people and things - are assembled and their realities, such as assignments, are constituted (Fenwick \& Landri 2012). It is within these new entanglements that we have developed and applied our methods, and argue for an evolution in the traditional ethnographic 'toolkit' of literacy researchers to include ways of documenting interactional practices which intertwine online and offline actors.

\section{Literacy's ethnographic toolkit}

This paper is primarily about our explorations with research methods, as we sought to better understand how learners, like Sara, get work done in classrooms using the various institutional and personal digital media at their disposal. As we shall see later in a deeper discussion of the above vignette, many of Sara's digital literacy practices are elided from view in a traditional methodological set up, and brought to the fore through precisely the type of methods we pioneer in our studies and propose in this paper. Specifically, we reflect on capturing and analysing how learners like Sara 'work' during classroom activities. We write 'work' here in quotes as we explore and problematise the practices and processes which give phenomena such as student work or play their character, how they are made sense of and practically achieved. Through 'diving deep' into digital literacies, we reveal a blurring of distinctions between ostensibly curricular usage of digital media and personal usage of it. In addition, we expose a linking of online and offline practices as part of the choreography of practices drawn into class work. This is because practices of all types find their way into, and support the completion of, Sara's work. This forms the basis of our contention: that the uncovering 
of such otherwise elided and 'sub rosa' (de Roock 2015; Gilmore 1986) practices requires methods of research which attend in detail to how classroom activities actually get done, their 'secret business' (Bigum et al. 2014). Literacy and educational researchers should therefore pay careful attention to the whole ecology of a given literacy event through a sequential analysis that captures related actors across time and space. Our methods comprise one example of this. These practices furthermore influence evolving scholarly ideas of digital literacy and learning and expand it beyond standardised and normative conceptions imposed by institutions like Sara's college.

Drawing from three methodologically similar studies conducted across the UK, Japan, and the USA, we present a reflection of the methodological and technical challenges faced during our research processes. These reflections, we argue, support the developing scholarly conversation surrounding the problem of new methods in new literacies research (Asselin \& Moayeri 2010; Caperton 2010), Literacy Studies (Bhatt \& de Roock 2013; Albers et al. 2014), as well as methodological innovations in the social sciences more generally (Snee et al. forthcoming).

To illuminate these reflections, we explored at the start of this paper a brief excerpt of data - a deep dive - from one of our studies (adapted from Bhatt 2014) as a representative example of the kinds of data that can emerge through the methodology we propose. In the following sections we orient the general reader to our disciplinary and theoretical influences, and further discuss what this deep dive excerpt of Sara's assignment writing yielded. This is followed by a reflection on how our combined interest in video ethnography and analysis, alongside the utility and affordances of CAQDAS ${ }^{3}$ tools to manage data, can push the boundaries of literacy research. We then

\footnotetext{
${ }^{3}$ Computer Aided Qualitative Data Analysis Software
} 
apply this understanding to our explorations of digital literacy in classrooms, and advance a methodology that we believe enhances not just the field in which the research is positioned, Literacy Studies, but also for the Learning Sciences and social research generally.

\section{The changing nature of Literacy Studies}

Paradigmatic shifts in how literacy is construed (e.g. Street 1984; Hamilton, Barton \& Ivaniç 1994; Baynham 1995), and how it is researched, make a distinction between types of literacies (with a plural), and a singularly conceived Literacy (with a singular). Literacies - in the plural - highlight the broad range of practices that can be characterised as literate activity. Works in the field of Literacy Studies thus draw attention to an 'autonomous' character of a singularly conceived literacy, which implicates power relations and is 'embedded in specific cultural meanings and practices' (Street 1995: 1). It embraces the thesis that literacies emerge in social practices and are 'ideological', subsuming the autonomous model which positions literacy as a 'uniform set of technical skills' (Street 2001: 2) to be applied the same everywhere; literacy practices therefore are ways of 'thinking about doing and reading in cultural contexts' (Street 2001: 11). As a result of this theoretical view of literacies as primarily social, Literacy Studies perspectives take context as their starting point, and indeed, main focus of enquiry.

Following this, in order to ethnographically explore the literacies of particular contexts, literacy researchers have made a distinction between 'literacy events' and 'literacy practices' (Street 1988; Barton \& Hamilton 2012). The 'event' construct draws 
from the sociolinguistic idea of 'speech events' (Hymes 1972), and has been developed upon in a number of seminal studies of literacy (e.g. Heath 1982; 1983). Specifically, it refers to the observable and empirical activities integral to a text. Literacy practices, then, draw a lens upon the 'social practices and conceptions of reading and writing' (Street 1984: 1). What becomes central, therefore, in the exploration and analysis of literacy events is the 'configuration of action, talk and text' (Prinsloo \& Baynham 2008: 4) and the conflation of interests (e.g. social, material and political) played out through the literacy practices that ensue.

In focusing on classroom based literacy events, our studies build on this research tradition which, initially, turned researchers away from pedagogic domains, as literacy began to be seen as not just confined to an instructional environment. In this vein, and through the broader conceptualisation of 'literacies', Literacy Studies research turned its attention to the vernacular practices of people in their everyday lives. But insights uncovered in these 'everyday' spheres entail, Ivanič (2009) contends, a need to return back to pedagogic spheres in order to complete the process of 'fine tuning literacy for learning' (ibid: 109). In other words, Literacy research moved from the classroom to the everyday, in order to return—with great improvements—-back to the classroom again, with the aim of bringing 'the lens of literacy studies to bear on learning and teaching' (ibid: 101). Notable studies which explore the interpenetration of classroom versus everyday literacies include Dyson's (2002) illustration of the hybridisation of in- and out-of-school literacy practices in writing tasks, Maybin's (2007) analysis of how official literacy activities are intertwined with informal practices and procedures, and Wortham's (2006) analysis of the interconnections between social identification in the classroom and academic learning. 
Building on these traditions, our research efforts discussed in this paper attempt to conceptualise the multi-layered interface between the literacies of social lives and those of normative classroom practice. They uncover how sets of practices can be cleverly and sometimes surreptitiously mobilised as resources by learners such as Sara, through an exploration of her practices of digital literacy in the moment-by-moment unfolding of her class work (much of which is digitally-mediated). But, in contrast to prior work, we ground our discussion in methods to present an account of how we captured the complex nature of student engagement with technologies in curricular tasks. Therefore, in order to situate our research better, and extend the current body of knowledge in literacy research, this leads us to the section below in which we outline our approach to 'digital literacies'.

\section{Literacies and the 'digital'}

Explorations of digital technologies, and the kinds of literacy practices that emerge from them, is part of a recently established thread of research within Literacy Studies (e.g. Gee 2012; Gourlay, Hamilton \& Lea 2014). Through an autonomous framing of Literacy, 'digital literacy' is often perceived as the requirement - in a digital environment - of being able to function effectively and utilise digital platforms, devices, and communications systems (e.g. Gilster 1997). This perspective is often reflected in policy discourses and its adoption often results in initiatives to 'upskill' and 'train' staff and students of educational institutions in how to develop their digital literacy (e.g. Hargittai 2009; Paynton 2012).

Following a broadening of the conceptualisation of digital literacy, commensurate with a Literacy Studies focus on the social practices and their contexts, 
there has been a wave of studies exploring the complex and sophisticated ways people use cyberspace and digital media in their lives. This research has focussed on activities such as gaming (de Roock 2015; Gee 2004; Steinkuehler 2007), online writing communities such as Fanfiction.net (Black 2008), and online participatory cultures (Jenkins et al. 2006). Notably, Mills (2010), in her review of research into digital literacy which draws largely from a Literacy Studies perspective, argues that:

The most recent, significant shift in this field has been what could be called the 'digital turn' - that is, the increased attention to new literacy practices in digital environments across a variety of social contexts. (Mills 2010: 246-274)

Previous work has also attempted to highlight the multimodal character of such literacies. For example in the work of the New London Group (1996) the term 'multiliteracies' stresses the different modes of representation other than the printed word (Cope \& Kalantzis 2000). Digital literacies are therefore inherently multimodal, and this expands the researcher's province of interest and analytical lens to include not just the mediating text and spoken meanings but also the wider context in which the literacy activity is taking place. In a classroom context, there can be a variety of static and portable devices being used, such as desktop computers, laptops, tablets and other devices which offer a wider range of mobility and modes. These developing avenues of research inquiry, and the issues that they attempt to uncover, highlight the need for new methodological approaches to explore how digital literacy practices saturate the new and developing classroom ecologies.

Our conceptualisation of 'digital literacies' therefore draws from the interdisciplinarity of digital literacy studies and multimodality, and involves a shift in mind-set from one which perceives literacies as simply more 'technologised' due to 
new media, to one that acknowledges them as radically re-shaping and re-organising societies. For us, practices of digital literacy must therefore go beyond what has traditionally been understood as mere activities where text has a role, to ones where 'digital codification' and 'digital enculturation' (Lankshear \& Knobel 2008: 5-7) are central.

When it comes to capturing digital literacy practices, in order to problematise how technologies mediate meanings and the creation of texts, traditional methods fall short. Some digital literacy practices are virtually invisible, inaccessible, or unanalysable using traditional research methods. Take, for example, those of Sara's practices which were fleeting and capricious yet drawn into her work as vital components to its completion (discussed further in the section below). New digital methods, in turn, also pose new practical and theoretical challenges, some of which we address in the following sections.

\section{Towards methodological evolution}

Literacy Studies has traditionally drawn upon a wide range of methodologies from across the social sciences and arts and humanities. These include ethnography, case study strategies, practitioner-based and action-research approaches, linguistic (including conversational analysis) and multimodal methods, as well as hermeneutic and arts practice methodologies (Albers et al. 2014). Each methodological approach has afforded new insights into the literacy practices of a particular context.

Our discussion here of the inclusion of more 'tools' in the exploration and analysis of digital literacies is positioned within a growing line of inquiry in Literacy Studies which raises the need to explore artefacts, physical settings and broader 
activities as part of literacy ethnographies (e.g. Barton 2012). Two other key figures in Literacy Studies, Heath and Street (2008), also stress the need 'to track, describe, and enumerate multimodalities as semiotic resources in their combinations' (p. 21) in literacy ethnographies. Following this, there has emerged research which effectively combines both multimodality and literacy (e.g. Kalantzis, Cope \& Cloonan 2010; Pahl \& Roswell 2011), but without theorising new research methods alongside emerging digital literacy practices. Building on this, we contend for the need to employ digitallysuited methods for the management and analysis of digital texts as they unfold. To us this is significant, yet often overlooked, especially when assessing the effectiveness and influence of digital media in classrooms and the confluence of practices in Cyberspace. For example, in Mills' (2010) review of ten years of research as part of the 'digital turn' within Literacy Studies, she covers a wide range of research in the field but with little mention of methodological evolution as part of this.

Digital media are so diverse that different situations and scenarios may involve a wide range and combination of resources within the same event, such as the writing of an assignment. There is also the potential of personal devices and ostensibly noncurricular digital literacy practices (such as personal messaging) influencing the event unfolding, and this then enters the purview of the researched site. Effectively capturing this confluence of practices as a data set, to know exactly how educational technology is being utilised in classrooms, becomes an urgent methodological challenge.

A number of scholars (e.g. Caperton 2010; Fields \& Kafai 2009; Gee 2015; Leander 2008), drawing largely on insights from the analysis of digital gaming environments, stress the need for researchers to explore and refine innovative methodological approaches for investigating forms of learning and literacy in digital environments - forms that are difficult to examine using traditional methods. 
Considering these issues, and through developing a sensibility to take different kinds of evidence into account, comes the need to adopt new methods in order to capture digital literacy practices and expand scholarly ideas. Many of these practices are elided from view in a traditional methodological set up, and brought to the fore through precisely the type of methods we propose.

The aims of the studies we discuss in this paper were to capture raw data of digital literacies being enacted in real time in key pedagogic literacy events such as assignment writing and classroom project work. The methods we employed needed to be agile enough to capture the kinds of practices emerging through the wide range of modalities (digital and paper texts, talk, audio, image, etc.) at play in the classroom. These multiple layers of modal resources give the literacy event its character. This aspect is salient, as the kinds of data emerging from their exploration and the chosen analytic framework to make knowledge claims need to take account of this modal complexity in order to capture the configuration of 'action, talk and text' of a literacy event (cf Prinsloo \& Baynham 2008). This necessary shift is in contrast to more traditional ethnographic traditions which orient researchers towards a reliance on textbased transcripts supported by still images, and leads us to the practices of production, mediation, appropriation and recycling between texts, platforms and devices.

\section{The studies}

Having addressed the methodological lacuna in literacy research, we now briefly outline the methodologies of our three research studies as a basis of our broader discussion in this paper. The common motivation across these studies was to understand the complex nature of digital literacy practices and the elements - social and material - that facilitate 
their unfolding in classroom spaces. Research was carried out in three uniquely different classroom contexts: a UK Further Education college (Bhatt 2013; 2014), a Japanese University (Adams 2013), and a US 6th grade classroom (de Roock 2015).

All of our studies sought to capture ongoing streams of concurrent online and offline activities during class work to explore the construction of meanings, choreography of digital literacy practices, and other supporting interactions. We therefore remain committed to the ethnographic tradition of Literacy Studies, but also draw from ethnomethodology to closely examine the practices and processes that hold up and maintain the particular social order and character to activities such as student 'work' or 'play' as stated at the start of this paper. Concretely, this means analysis of how the students (and teachers) make sense of and accomplish their everyday tasks based on the resources evident to them in the immediate setting, rather than through any researcher imposed frameworks, theories, or discourses.

This is achieved in both Bhatt's and de Roock's studies through a particular iteration of ethnomethodology which draws from the field of video analysis (see Bhatt \& de Roock 2013 for a fuller theoretical discussion of this method) to conduct microanalyses of specific salient moments situated in the broader systematic approach to ethnographic data. This served as a useful analytic framework for problematising interactions and activities between actors in the accomplishment of class (and non-class) work (teacher, students, whiteboard, Web pages, algorithms, assessment criteria, etc.). In Adams's study the analytic framework adopted was based on the principles of multimodal analysis (Norris 2004) facilitated by the same methods of multiple video angles and screen recording. This focussed on the exploration of meanings constructed through repetitive and patterned practice beyond spoken discourse. 
In the approach represented by our three studies, the central focus was the semiotic and material resources drawn upon by participants (e.g. gesture, gaze, spoken language, images, web interactions, texts, etc.) and the broader practices emerging in the unfolding of their class work and play in the classrooms. While traditional ethnographic methods allowed the identification and broader contextual features of such digital literacy practices, additional video analysis methods were needed for a more robust investigation of their unfolding and close examination. Screen activity was also captured in a manner that allowed for a screen-in-screen (see Figure 1) format to conflate video recordings of students' movements around the tasks. In some cases, drawing from Flewitt (2006), a descriptive video log of the entire recording was then created and clips selected for repeated viewing and more in-depth analyses. These were then adapted into descriptive vignette accounts of the sessions, as presented in the opening section, to facilitate analysis, writing, and presentation of the research.

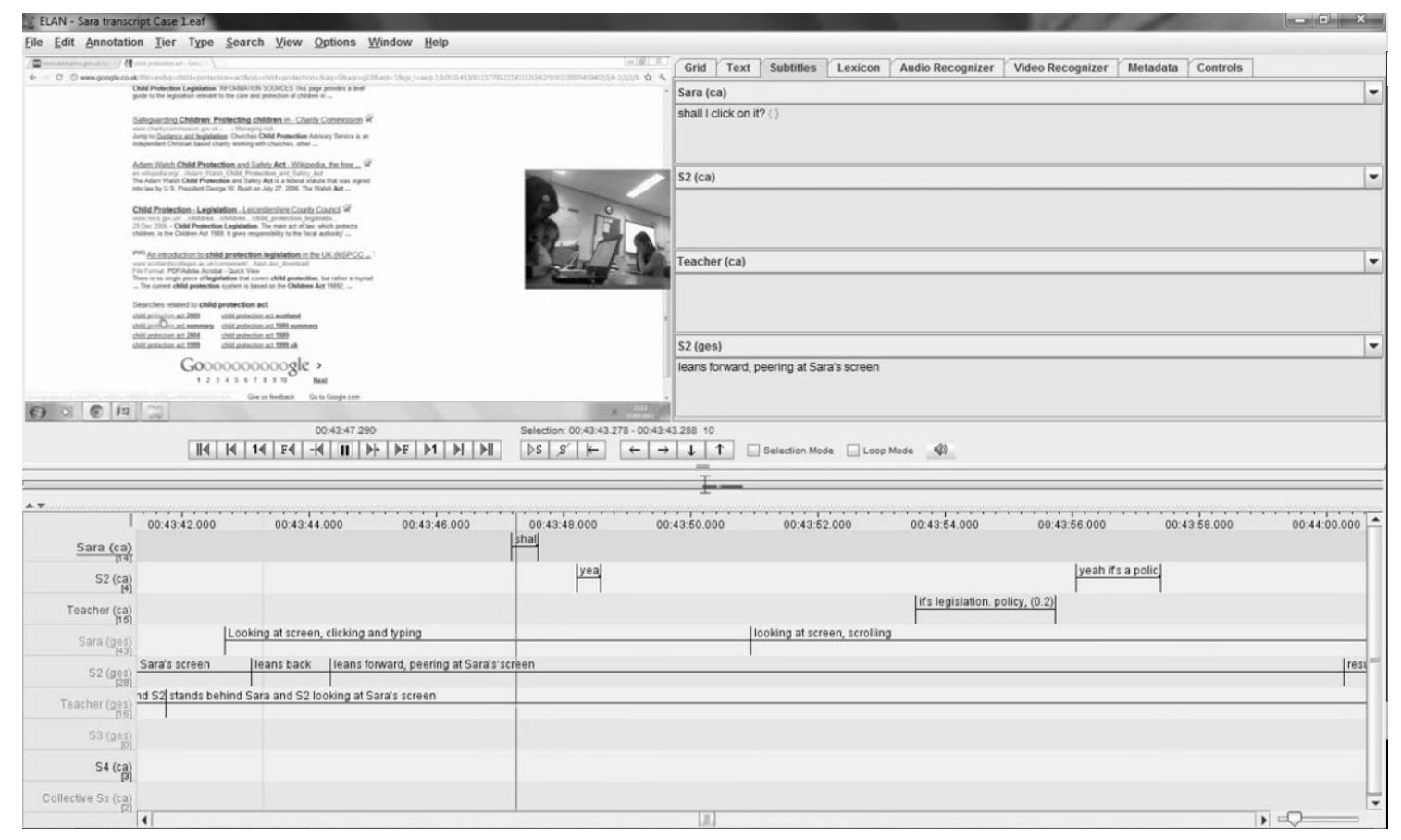

Figure 2: The representational system of ELAN with a horizontally aligned transcript 


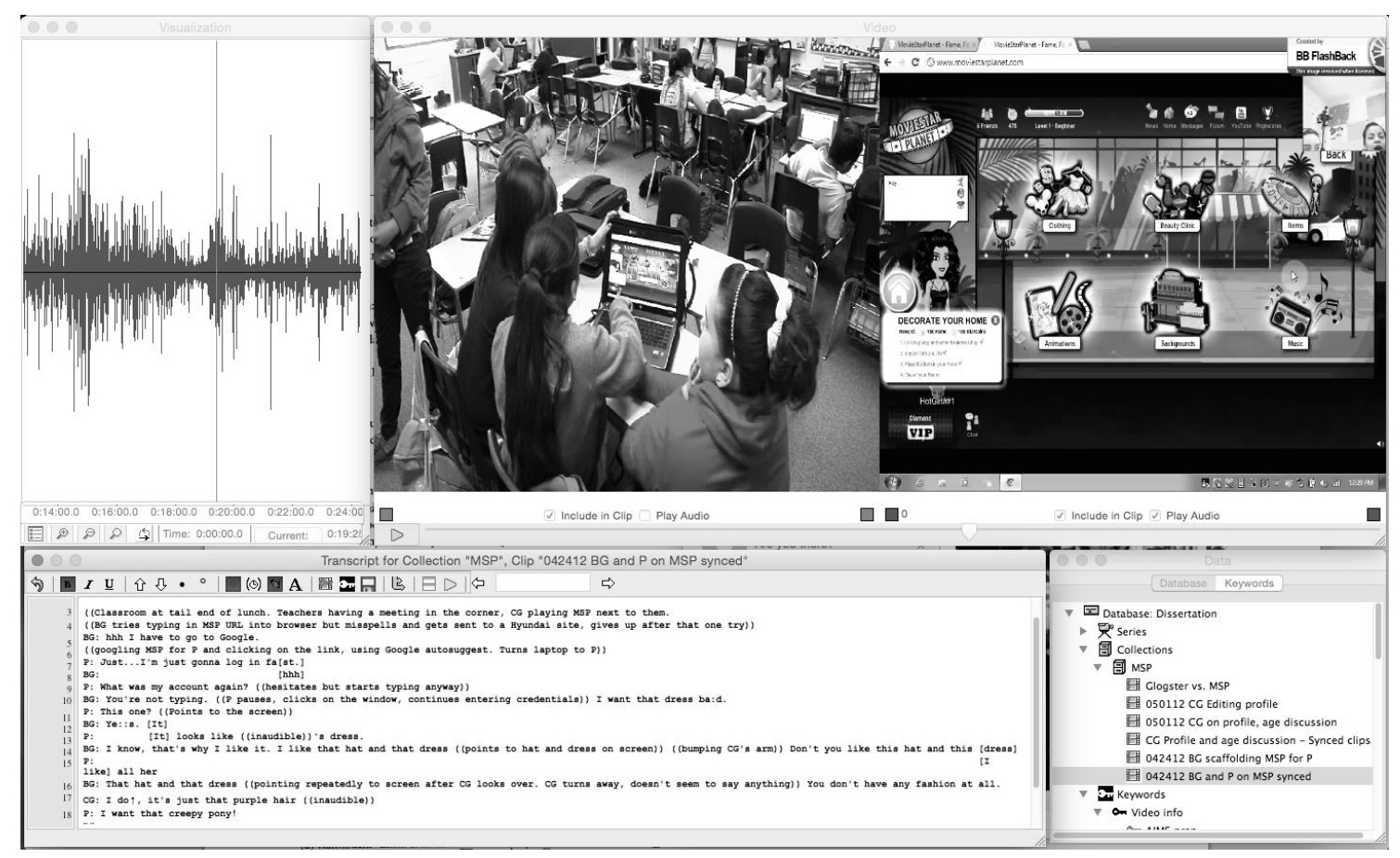

Figure 3: The single transcript system with multiple synced recordings, using Transana

\section{Summary findings}

We now return to the vignette account at the start of the paper, and explore some of its insights in more depth, augmented by selected elements from two other studies (de Roock 2015 and Adams 2013) in order to explicate how such findings are representative of the insights which can emerge through the kind of close examination we propose.

As soon as Sara's session begins, and without a moment's hesitation, she opens an assignment from a previous unit criterion as a basis upon which to begin the current task. What is then written by Sara for this assignment is her own synthesis and interpretation of the two criteria; in this way previous work serves an important role throughout her writing process. The perfunctory automation with which she draws from 
the past as she mobilises previous texts into a purposeful (re)use in this assignment tells us about how she approaches what is expected of her, as she thinks back and refers to the regulations and practices that have informed her previous work. This provides Sara with validation of how to work in the present: outlining the font to be used, stylistic considerations (headings, title, etc.), content and the length of the piece.

Later, as she further considers ways of how to integrate the contents of previous assignments into the current one, she opens a group of files and, as a tactic, scrolls through them discussing with Lauren (seated beside her) what particular aspects of the previous files (on 'legislation' and 'policies and practices') relate to the work that needs to be done now (on 'child protection'), and which aspects do not. At this stage the requirements of the current assignment are being negotiated with the criterion on the whiteboard, previous criteria, previous assignments, Sara and Lauren's prior knowledge, the teacher's notes and instructions, and guesswork between all of these vital interacting elements. All of these, within this brief excerpt, entail a juggling of certain digital literacy practices that occur as a confluence and are quite complex and sophisticated, yet also fleeting, in their nature.

Furthermore, as Sara was continuously figuring out what is required of her and asking the teacher and her immediate peer (Lauren), we observe an obvious task to be completed: an assignment. But nested within this task remain a multitude of other subsidiary tasks: to draw resources from the college's virtual learning environment (VLE), a requirement to search certain Web pages for policies, to then synthesise the ways these policies have been implemented in Sara's particular work setting, to then submit the assignment via the VLE (in line with the institutional procedure). These 'hoops' to 'jump through' also entail digital literacy practices but are more formalised 
in nature, at least from the college's perspective, than Sara's preferred copy and paste work-around (i.e. from previous assignments). The tactics and procedure emerging are both through the teacher's explicit instructions, which channel a certain kind of digital media use, but also implicit and even anarchic when muttered under the breath of Lauren. Namely, her suggestion to 'just copy and paste .... cos it's our own words anyway', and also later as she contacts a friend via a social network to ask for help related to her work.

Similarly, Adams's study of Japanese university students during classroom activities revealed that a wide range of communicative modes were employed as they discussed video texts with each other. These modes emerged through shifts in speaker, digital texts, gestures, gaze, and proxemic relations between the learners and other tools (such as the computer mouse and pens). They were, as a whole, fundamental to overall meaning-making strategies. These shifts in modal configurations, or modal complexities (Norris 2004, pp. 79-80), were directly related to the media and their affordances. For example, the digital texts had controls to stop, pause and search for specific parts in the stories. As a result, the participants employed their hands, arms and gaze to interact with the texts through the mediating digital devices, with some movements and gestures less than a second long. This involved such things as using the trackpad or mouse of the computer, as well as functions within the keyboard as part of direct interpersonal communication. As with Sara, this study revealed that material properties and their arrangement within the task is embedded within communication practices and subsequently requires a certain approach to the collection and analysis of data to be explored effectively.

Also leveraging the analysis of multiple video data streams along with 
ethnographic field notes, de Roock's study reconstructs the ecology of classroom interaction and literacy practices. Echoing what was observed with Sara, the focus on capturing sub rosa literacies (Gilmore 1986) enabled the examination of a rich classroom underlife (Goffman 1961) established by student 'off-task' behaviour, including the surreptitious playing of a multiplayer online game to engage in personally meaningful identity work and participation in online and offline communities of practice. The practices of this peer group's underlife were beyond the teacher's immediate gaze, yet consistent and paired recording afforded rich capture of their moment-by-moment construction. This problematises dichotomous notions such as inschool/out-of-school or formal/informal literacies, arguing that (as in Goffman's original study of public institutions) such peer practices help to maintain, reinforce, and make possible the standard and more valorised classroom practices.

\section{Key challenges}

The choices made in developing research and analytic methods themselves highlight the entangled nature of learning practices as exemplified by Sara earlier. Emerging from and guided by theories of the performativity of practice, the research process is heavily guided by the constraints and affordances of fieldwork technologies and the representational work which this ultimately performs. The social relations and interactions of fieldwork are inseparable of course, but here we artificially parse out the methodological and technological challenges we faced for more detailed examination.

\section{Methodological challenges}

There are always challenges present in developing a strong research design. Participants 
of research can, and likely do, behave differently when they know that they are being observed, recorded, and even more so alongside their monitored screen activity (Tang et al. 2006). Such multiple representations of what students write, see, hear and vocalise around a task will doubtless have methodological constraints and challenges.

For example deciding what to focus on in Sara's case-study across the unfolding text on her screen, her gestures to the screen and to others, and her surrounding talk, etc. was something decided early on. This was to avoid a type of data saturation brought about by a potentially overwhelming amount of data. The extraordinary detail and complexity of such data can make the process after initial classification very impractical. In line with Heath et al. (2010), segments of approximately ten seconds, were selected and viewed repeatedly and then rendered into typed logs of activity. Selection can be based on a range of concerns influenced by the research questions, observational notes, and other relevant and supporting data (e.g. interviews) which emerge during the research inquiry.

Presentation of the resulting multimodal data posed a particular set of problems due to the limited scope of two-dimensional formats such as a thesis or research paper. With such multiple forms of data also come the challenges of interpreting these different sources as a complete whole, in a balanced manner. Meanings being analysed are broken up into different camera angles, audio, screenshots and need to be 'united' by the researcher. The complexity of multiple sets of data and 'how the different media 'speak' to each other' (Flewitt 2011:295) need to be considered.

\section{Technical challenges: CAQDAS}

Both hardware and software tools have come a long way over the last two decades. Now both usability testing software (e.g. Morae Recorder) and screencast software have 
the ability to capture both on-screen activity, surrounding audio, and webcam footage with considerably less practical difficulty. Additionally, they may be captured on different devices and later combined, although few data analysis programs support the ability to sync data types and create shared transcripts based on them. Transana is one of the few programs that makes this possible.

Although the combination of these techniques, as used in our studies, helped alleviate some of the limitations of using video recordings alone for data capture and analysis, the capture of our simultaneous renditions poses new methodological challenges. In the case of Sara, the complete workflow involved was not anticipated fully in initial research design, as challenges arose during the research process. These included such things as the extent of her interactions with others beside her, with the rest of the class, and the sheer profusion of practices online, and their collective importance to the completion of her assignment.

For example, transcription preparation of salient segments of her recording was carried out using the CAQDAS tool known as ELAN (Figure 2) and, in another one of our studies, with Transana (Figure 3). These allowed for deeper insights into the character of crucial interactions and critical moments during classroom activities. The CAQDAS tools we used afford manipulability (slowing down, segmentation, etc.) and multimodal conventions (Bezemer \& Mavers 2011) to account for the host of interrelated behaviours (including gaze, surrounding talk, and interactions with Web sites and search algorithms). The subsequent representational system which emerged integrates the modes of actors' activities as student work was being done.

It is important to note that no single device or software will accomplish everything. This necessitates trialling and experimenting with different tools and softwares over time to see which will be the most useful in 'recreating' the literacy 
event. This involves setup of camcorders and microphones, transcribing, to saving of screencast files. This also requires a certain thinking ahead in terms of displaying transcripts and other data representations. Multimodal video transcripts work within a published dissertation, but may need converting to a vertical format for more traditional journals. In the case-study of Sara, this was possible using ELAN, but having to think about the end representation, in turn, shapes the analysis process.

In this vein, in selecting CAQDAS platforms, it is important to note that designers' epistemological assumptions are built into all data capture and/or analysis tools. It is therefore not enough to choose the 'best' one that matches the objectives of the research, but to also be reflexive about how a researcher, and their tools and apparatus, are entangled in the observed phenomenon and shape the emerging research (see Bhatt \& de Roock 2013 for a fuller account).

\section{Technical challenges: screen-in-screen}

There are always technical challenges in using video equipment in research (Spiers 2004), whether this is about camera and microphone placement or data file management. Recent advancements in video and audio recording equipment allow researchers to use unobtrusive tools which work in the background. Examples of this from Sara's case-study set up include the use of an omnidirectional microphone, USB attached HD Webcam, and the use of screen recording software to capture all on-screen activity without the use of external cameras pointed towards the screen.

However, increased complexity of captured data, in the manner proposed here (e.g. screen-in-screen recordings), produces rather large files and poses a host of related technical challenges. When taken from numerous computers and a paired wide angle 
camera (as undertaken in de Roock's study), a single session will result in several gigabytes of file storage. Alongside the screen capture, which must also be exported to an appropriate video format for analysis, the process becomes time consuming and can take considerable storage space.

In our studies, screen-in-screen files were first edited with the webcam image reduced and placed in a corner, then converted to a more manageable file format to minimise processing demands on the computer. In de Roock's case (see Figure 3), the files were reduced in size to approximately $500 \mathrm{Mb}$ (from about $1.3 \mathrm{~Gb}$ ) in order to play three videos simultaneously. This is where software such as Transana is essential, and makes the process of analysing multiple and simultaneous sources of data relatively easy once the data have been synced accurately.

Despite our cameras being generally less intrusive due to their small size, and affording a large amount of captured visual detail, they created very large files. In the case of Sara's assignment, these files were difficult to play simultaneously on the ELAN software, so they needed to be reduced in size by about $90 \%$. Even though this is not particularly challenging, it added another layer of researcher work, and the requirement of a very powerful computer to handle such files smoothly.

The evolution of these technologies and software programmes need to keep up with the rapid development of digital technologies in classrooms and personal lives. Additionally, with portable and wearable devices now integral to everyday social practices, they are part of a literacy researcher's province of interest and likely to soon play a role in literacy research. 


\section{Concluding comments}

What can seven minutes of video with screen recording in this methodological setup reveal? As a 'deep dive', what is striking is that a close examination of these initial but vital - six and a half minutes of Sara's assignment exemplifies her digital literacy practices as multi-layered and unbounded phenomena. This is evident through the ephemeral infiltrations of practices that would otherwise be considered 'personal' or 'vernacular' in nature and therefore not deemed by the college as supportive to her work. Crucially, our methods have allowed us close access to the entanglement and interdependence of online and offline practices in the doing of class work. What emerges is a choreography of practices which, when taken together, give 'work' its appearance and character, but when closely examined are precariously connected to any a priori notion of what class 'work' actually is.

These findings are significant as they serve to reinforce the highly complex nature of student engagement with technologies in curricular tasks, and undermine a monolithic, a priori, or institutionally imposed understanding of what 'digital literacy' and 'digital learning' should entail for learners like Sara. Importantly, our methods can support an emerging transdisciplinary discussion of methods across the social sciences (e.g. Snee et al. forthcoming). These include such methods as online and Internet ethnography (Hine, 2004) and 'connective ethnography' (Leander, 2008).

Whilst our studies are grounded in the ethnographic and critical tradition of Literacy Studies, we feel that the nature and character of literacy practices in digital environments requires a transformation in methods. This is not incommensurate with early works in Literacy Studies (e.g. Street 1984; Hamilton, Barton \& Ivaniç 1994; Baynham 1995) which were paradigmatic and methodological evolutions to traditional 
notions of a) what literacy is, and subsequently b) how it is to be researched. In order for inquiries inspired by Literacy Studies to further apply their ethnographic power and their critical lens when exploring digital literacies, another evolution in methods may have to occur, one which is more sensitive to the unique character of semiotic exchange and literacy practices in digital environments. In this vein, we found that there is much to be gained by a composite picture of real-time interactions around assignment activities in classrooms. Understanding how the combination of methods pioneered in our research can be appropriated in different ways and enhanced (e.g. with usability testing software) can lead to exciting possibilities as well as an array of new questions to enhance a researcher's interpretive process. As literacy research redirects its attention to educational contexts, we hope our reflections can contribute to the growing discussion around the technologies of methods to capture the evolving nature of literacies.

\section{References}

Adams, J. (2013) Analysing the Construction of Meanings With Mediating Digital Texts in Face-To-Face Interactions. Unpublished $\mathrm{PhD}$ thesis, Lancaster University.

Albers, P., Holbrook, T. \& Flint, A. (2014). New Methods of Literacy Research. Abingdon: Taylor \& Francis.

Asselin, M. \& Moayeri, M. (2010). New tools for new literacies research: an exploration of usability testing software. International Journal of Research \& Method in Education, 33 (1), 41-53.

Barthes, R. \& Heath, S. (1977). Image, music, text. London: Fontana.

Barton, D. (2012). Ethnographic Approaches to Literacy Research. In: The Encyclopedia of Applied Linguistics Blackwell Publishing Ltd.

Barton, D. \& Hamilton, M. (2012). Local literacies: reading and writing in one community. London: Routledge.

Baynham, M. (1995). Literacy practices: investigating literacy in social contexts. London; New York: Longman.

Bezemer, J. \& Mavers, D. (2011). Multimodal transcription as academic practice: a social semiotic perspective. International Journal of Social Research Methodology, 14 (3), 191-206.

Bhatt, I. (2012). Digital literacy practices and their layered multiplicity, Educational Media International, DOI: 10.1080/09523987.2012.741199, 49(4), pp. 289-301. 
Bhatt, I. (2013). The sociomaterial workings of a college writing assignment, The Society for Research into Higher Education (SRHE) Annual Research Conference 2013 (reviewed proceedings), 'Experiencing higher education: Global Trends and Transformations' (Dec, 2013).

Bhatt, I (2014) A sociomaterial account of assignment writing in Further Education classrooms, $\mathrm{PhD}$ thesis (submitted: Nov 2014), School of Education, University of Leeds.

Bhatt, I. (2014b) Curation as digital literacy practice [online, accessed $3^{\text {rd }}$ Jan 2015] http://ibrarspace.net/2014/05/21/curation-as-a-digital-literacy-practice/

Bhatt, I. \& de Roock, R. (2013). Capturing the sociomateriality of digital literacy events. Research in Learning Technology, 21 (4).

Bigum, C., Rowan, L., Wright, S., Hamilton, M. \& Haxell, A. (2014). Looking for black cats and lessons from Charlie: exploring the potential of public click pedagogy (February 2014 version of Working paper). Updated 8th April 2014. 9th April 2014]. Available from http://chrisbigum.com/downloads/PCP-NLC.pdf.

Black, R. W. (2008). Adolescents and online fan fiction. New York; Oxford: Peter Lang.

Caperton, I. H. (2010). Toward a Theory of Game-Media Literacy: Playing and Building as Reading and Writing. International Journal of Gaming and Computer-Mediated Simulations (IJGCMS), 2 (1), 1-16.

Cope, B. \& Kalantzis, M. (2000). Multiliteracies: literacy learning and the design of social futures. London: Routledge.

de Roock, R. (2015) Digital Literacies as Interactional Achievements: A Multimodal Approach to Understanding Learning with New Digital Media. (Unpublished doctoral dissertation), Tucson, AZ, University of Arizona.

Dyson, A. H. (2003). The Brothers and Sisters Learn to Write: Popular Literacies in Childhood and School Cultures. New York: Teachers College Press.

Fenwick, T. \& Landri, P. (2012). Materialities, textures and pedagogies: socio-material assemblages in education. Pedagogy, Culture \& Society, 20 (1), 1-7.

Fields, D. \& Kafai, Y. (2009). A connective ethnography of peer knowledge sharing and diffusion in a tween virtual world. International Journal of ComputerSupported Collaborative Learning, 4 (1), 47-68.

Flewitt, R. (2006). Using video to investigate preschool classroom interaction: education research assumptions and methodological practices. Visual Communication, 5 (1), 25-50.

Flewitt, R. (2011). Bringing ethnography to a multimodal investigation of early literacy in a digital age. Qualitative Research, 11 (3), 293-310.

Gee, J. P. (2004). Situated language and learning: a critique of traditional schooling. New York; London: Routledge.

Gee, J. P. (2012). The Old and the New in the New Digital Literacies. The Educational Forum, 76 (4), 418-420.

Gee, J. P. (2015). Unified Discourse Analysis: Language, Reality, Virtual Worlds and Video Games. Abingdon: Routledge.

Gilmore, P. (1986). Sub-Rosa Literacy: Peers, Play and Ownership in Literacy Acquisition. In: Schieffelin, B. B. \& Gilmore, P. (Eds.) The Acquisition of literacy: ethnographic perspectives (pp. 155-168). Norwood, NJ: Ablex Pub. Corp.

Gilster, P. (1997). Digital literacy. Chichester: John Wiley.

Goffman, E. (1961). Asylums. Essays on the social situation of mental patients and 
other inmates. Garden City, N.Y.: Doubleday \& Co.

Goodson, I. (2002). Cyber spaces/social spaces: culture clash in computerized classrooms. New York, N.Y.; Basingstoke: Palgrave Macmillan.

Gourlay, L., Hamilton, M. \& Lea, M. R. (2014). Textual practices in the new media digital landscape: messing with digital literacies. Research in Learning Technology, 21 (4).

Hamilton, M., Barton, D. \& Ivaniç, R. (1994). Worlds of literacy. Clevedon: The Language and education library, Multilingual Matters.

Hargittai, E. (2009). An Update on Survey Measures of Web-Oriented Digital Literacy. Social Science Computer Review, 27 (1), 130-137.

Heath, C., Hindmarsh, J. \& Luff, P. (2010). Video in qualitative research: analysing social interaction in everyday life. Los Angeles; London: SAGE.

Heath, S. B. (1982). What No Bedtime Story Means: Narrative Skills at Home and School. Language in Society, 11 (1), 49-76.

Heath, S. B. (1983). Ways with words: language, life, and work in communities and classrooms. Cambridge: Cambridge University Press.

Heath, S. B. \& Street, B. V. (2008). On ethnography: approaches to language and literacy research. London: Routledge.

Hine, C. (2004). Social research methods and the Internet: A thematic review. Sociol. Res. Online, 9 (2).

Hymes, D. (1972). Editorial Introduction to Language in Society. Language in Society, 1 (1), 1-14.

Ivanič, R. (2009). Bringing literacy studies into research on learning across the curriculum. In: Baynham, M. \& Prinsloo, M. (Eds.) The future of literacy studies (pp. 100-122). Basingstoke: Palgrave Macmillan.

Jenkins, H., Clinton, K., Purushotma, R., Robison, A. \& Weigel, M. (2006). Confronting the challenges of participatory culture: Media education for the 21st Century. The John D. and Catherine T. MacArthur Foundation [online] Available at http://digitallearning.macfound.org/atf/cf/\%7B7E45C7E0-A3E04B89-AC9C-E807E1B0AE4E\%7D/JENKINS_WHITE_PAPER.PDF.

Kalantzis, M., Cope, B. \& Cloonon, A. (2010). A Multiliteracies Perspective on the New Literacies. In: Baker, E. A. (Ed.) The New Literacies: Multiple Perspectives on Research and Practice (pp. 61-87). New York: The Guilford Press.

Lankshear, C. \& Knobel, M. (2008). Digital literacies: concepts, policies and practices. Oxford: Peter Lang.

Law, J. 2012. "Collateral Realities.” In The Politics of Knowledge, edited by F.D. Rubio and P. Baert, 156-178. London: Routledge.

Lawless, K. A. \& Schrader, P. G. (2008). Where do we go now? Understanding research on navigation in complex digital environments. In: Coiro, J., Knobel, M., Lankshear, C. \& Leu, D. (Eds.) Handbook of research on new literacies London: Routledge.

Leander, K. (2008). Toward a Connective Ethnography of Online/Offline Literacy Networks. In: Coiro, J., Knobel, M., Lankshear, C. \& Leu, D. (Eds.) Handbook of research on new literacies (pp. 33-65). New York: Lawrence Erlbaum Associates/Taylor \& Francis Group.

Maybin, J. (2007). Literacy Under and Over the Desk: Oppositions and Heterogeneity. Language and Education, 21 (6), 515-530. 
Mills, K. A. (2010). A Review of the "Digital Turn" in the New Literacy Studies. Review of Educational Research, 80 (2), 246-271.

Norris, S. (2004). Analyzing Multimodal Interaction: A Methodological Framework. London: Routledge.

Pahl, K. \& Rowsell, J. (2011). The Material and the Situated: What Multimodality and New Literacy Studies Do for Literacy Research. In: Lapp, D. \& Fisher, D. (Eds.) Handbook of Research on Teaching the English Language Arts Oxon and New York: Routledge.

Paynton, S. (2012). Developing Digital Literacies: briefing paper. JISC, [cited 15th April 2013 Available from http://www.jisc.ac.uk/publications/briefingpapers/2012/developing-digitalliteracies.aspx.

Prinsloo, M. \& Baynham, M. (2008). Literacies, global and local. Amsterdam ; Philadelphia: John Benjamins Pub. Co.

Rheingold, H. (2012). Net smart: how to thrive online. Cambridge, Mass.; London: MIT Press.

Skaar, H. (2014). Writing and pseudo-writing from Internet-based sources: Implications for learning and assessment. Literacy, DOI: 10.1111/lit.12045.

Snee, H., Hine, C., Morley, Y., Roberts, S. \& Watson, H. (forthcoming). Digital Methods for Social Science. Hampshire: Palgrave MacMillan.

Snyder, I. (2015). Discourses of 'curation' in digital times. In: Jones, R., Chik, A. \& Hafner, C. (Eds.) Discourse and Digital Practices: Doing discourse analysis in the digital age (pp. 209-225). Abingdon: Routledge.

Spiers, J. A. (2004). Tech tips: using video management/analysis technology in qualitative research. International Journal of Qualitative Methods, 3 (1), 57-61.

Steinkuehler, C. (2007). Massively Multiplayer Online Gaming as a Constellation of Literacy Practices. E-Learning and Digital Media, 4 (3), 297-318.

Street, B. (1988). Literacy Practices and Literacy Myths. In: Saljo, R. (Ed.) The Written World: Studies in Literate Thought and Action (pp. 59-72). Berlin: SpringerVerlag.

Street, B. V. (1984). Literacy in theory and practice. Cambridge: Cambridge University Press.

Street, B. V. (1995). Social literacies: critical approaches to literacy in development, ethnography and education. London: Longman.

Street, B. V. (2001). Literacy and development: ethnographic perspectives. London: Routledge.

Tang, J. C., Liu, S. B., Muller, M., Lin, J. \& Drews, C. (2006) Unobtrusive but invasive: using screen recording to collect field data on computer-mediated interaction. Proceedings of the 2006 20th anniversary conference on Computer supported cooperative work. Banff, Alberta, Canada, ACM.

The New London Group (1996). A Pedagogy of Multiliteracies: Designing Social Futures. Harvard Educational Review, 66 (1), 60-93.

Wortham, S. (2006). Learning identity: The joint emergence of social identification and academic learning. Cambridge: Cambridge University Press. 